\title{
KEPATUHAN PENGGUNAAN OBAT DAN KUALITAS HIDUP PASIEN HEMODIALISA DI RS PKU MUHAMMADIYAH YOGYAKARTA PERIODE MARET 2015
}

\author{
Endah Karuniawati, Woro Supadmi*)
}

Fakultas Farmasi, Universitas Ahmad Dahlan, Yogyakarta, Indonesia

Received May 23, 2016; Accepted August 30, 2016

\begin{abstract}
The adherence holds an important role that can affect the success rate of the therapy and increase the life quality of the patients. Quality of life is an ability to reflect the health in the term of physically, psychology, and socially and the satisfaction of the patients' functional and control level. Research aims to understand relations compliance treatment with the quality of life can be measured by MMAS and WHOQOL questioners. The research applied descriptive, non experimental and crosssectional methods. The aim of the research was to find out the relationship between the medication adherence and the life quality of the hemodialysis patients. The medication adherence data was gathered by MMAS (Morisky Medication Adherence Scale) and the life quality was gathered by WHOQOL (World Health Organization Quality of Life) of hemodialysis patients at PKU Muhammadiyah Yogyakarta Hospital. The research results showed that from 101 respondents the medication adherence in the level of high 58,42\%, level moderate 8,91\% and low 32,67\%.).The quality of life of patients of the domain physical, mental, social and environmental at a high rate and low. Relations adherence the use of a drug with the quality of life of significant $(p<0,005)$ in all the domain. Compliance the use of drugs associated with the quality of life of hemodialysis patients at PKU Muhammadiyah Yogyakarta Hospital.
\end{abstract}

Keyword: adherence, life quality, MMAS, WHOQOL

\section{PENDAHULUAN}

Angka kejadian gagal ginjal di dunia lebih dari 500 juta orang dan harus mempertahankan dan menjalani hidup dengan hemodialisa sebanyak 1,5 juta orang. Prevalensi di Amerika Serikat yang menderita gagal ginjal sebanyak 300.000 dengan 220.000 yang menjalani hemodialisa. Di Indonesia prevalensi penderita gagal ginjal sebanyak 150.000 orang dan yang menjalani hemodialisa sebanyak 10.000 orang (Baradero et al, 2008).

Jumlah penderita ginjal kronik di Indonesia dari tahun ke tahun selalu meningkat, Indonesian Renal Registry menyajikan informasi yang dapat digunakan sebagai data base. Pada tahun 2009 prevalensi penderita gagal ginjal yang menjalani hemodialisa sebanyak 5.450, meningkat pada tahun 2010 sebanyak 8.034 penderita, dan tahun 2011 meningkat menjadi 12.804 penderita Jumlah pasien baru dan pasin aktif di Indonesia tahun 2012 adalah pasien baru 19.621 dan pasien aktif 9161 (IRR, 2012).
Pada tahun 2011 di Indonesia terdapat 15.353 pasien yang baru menjalani hemodialisa dan pada tahun 2012 terjadi peningkatan pasien yang menjalani hemodialisa sebanyak 4.268 orang sehingga secara keseluruhan terdapat 19.621 pasien yang menjalani hemodialisa. Sampai akhir tahun 2012 terdapat 244 unit hemodialisis di Indonesia (IRR, 2013).

Hemodialisa dapat digunakan untuk gagal ginjal akut maupun gagal ginjal kronik. Bagi penderita gagal ginjal kronik hemodialisa dapat mencegah kematian, namun hemodialisa bukanlah untuk menyembuhkan atau memulihkan penyakit ginjal dan tidak mampu mengimbangi hilangnya aktivitas metabolit atau endokin yang dilaksanakan ginjal dan dampak dari dari gagal ginjal serta terapinya terhadap kualitas hidup pasien (Brunner dan Suddarth, 2001).

Penanganan hemodialisa diantaranya yang bersifat subjektiftifitas dapat menyebabkan tekanan darah rendah, mual dan muntah, kulit 
kering dan gatal, sindrom kaki menjadi gelisah, kram otot, nyeri, sesak napas, kram perut. Sehingga setelah menjalankan terapi hemodialisa pasien diberi obat oleh dokter obat tekanan darah, diuretik, pengencer darah, pengikat fosfat, alfa calcidol, cinacalcet untuk pasien yang memiliki hormon paratiroid yang sangat tinggi, eritropoeitin, iron, tinzaparin, antimikroba atau anti bakteri, analgetik (antinyeri), sodium bikarbonat, obat untuk gout (allopurinol), dan kuinin sulfat untuk mengatasi dari efek samping tersebut (Carol, 2013).

Keberhasilan pengobatan tidak hanya terletak pada sarana atau fasilitas yang ada di rumah sakit, keterampilan tenaga medis dan pola hidup dari pasien, tetapi juga dipengaruhi kepatuhan pengobatannya. Hasil terapi tidak akan optimal tanpa adanya kesadaran dari pasien untuk mempertahankan hidupnya, dan dapat pula menyebabkan kegagalan terapi atau komplikasi yang merugikan dan berakibat fatal (Hussar, 1995).

Pentingnya kepatuhan penggunaan obat terutama untuk penyakit gagal ginjal yang membutuhkan terapi jangka panjang berhubungan dengan kualitas hidup pasien dan prevalensi gagal ginjal yang semakin meningkat pada setiap tahunnya merupakan alasan dilakukannnya penelitian yang berjudul "Kepatuhan pengobatan dan kualitas hidup pasien hemodialisa di RS PKU Muhammadiyah Yogyakarta". Selanjutnya penelitian ini dapat digunakan sebagai evaluasi dalam memperbaiki kepatuhan dan kualitas hidup pasien hemodialisa.

\section{METODE PENELITIAN \\ Rancangan penelitian}

Rancangan penelitian yang digunakan adalah penelitian observasional dan bersifat deskriptif dengan pendekatan cross-sectional.

\section{Pengumpulan data penelitian}

Pengumpulan data pasien hemodialisa dilakukan pada bulan Maret 2015. Data yang diambil meliputi nama, alamat, nomor telepon, dan obat yang diberikan setelah hemodialisa. Data mengenai kepatuhan pasien hemodialisa diperoleh melalui kuisioner MMAS yang diambil sebelum wawancara dilakukan atau pada sebelumnya dan kualitas hidup diperoleh dari kuisioner. WHOQOL (World Health Organization Quality Of Life) adalah intrumen yang mengukur kualitas hidup meliputi domain kesehatan fisik, kesehatan mental, hubungan sosial, dan lingkungan.

\section{Analisis Data}

Analisa data dan pengolahan data dilakukan dengan menggunakan paket program statistik. Analisis statistik dilakukan dengan meliputi langkah berikut :

Mengecek kelengkapan data, yaitu mengecek kelengkapan kuisioner jika ada kerusakan atau ketidaklengkapan pada halaman kuisioner ditukar dengan yang lengkap.

Skoring data kuesioner, adalah menghitung data kuisioner untuk setiap pertanyaan yang kemudian dijumlahkan. Untuk kuisioner WHOQOL setelah selesai dilakukan penjumlah skor pada tiap domain kemudian ditransfomasikan dalam rentang skor (4-20) dan skor (0-100) yang terlihat pada Tabel VII selanjutnya nilai kualitas hidup pasien dihitung dengan rata-rata dari transformasi skor 0100 dengan rumus :

\section{$\frac{\text { Domain } 1+\text { Domain } 2+\text { Domain } 3+\text { Domain } 4}{4}$}

Setelah selesai menghitung untuk setiap pertanyaan kemudian di total skor dari jawaban pertanyaan tersebut, di hiutng rat-rata pada setiap domain dan kemudian dihitung lagi responden yang memiliki skor diatas rata-rata, rata-rata dan dibawah rata-rata sehingga diketahui kualitas hidup pasien.

Analisis statistik yang digunakan adalah regresi linear untuk mengkaji hubungan antara satu variabel independent $(\mathrm{X})$ yaitu domain dengan variabel dependent (Y) yaitu kepatuhan. Batas kemaknaan akan diterima bila $\mathrm{p}<0,05$. 
Tabel I. Perhitungan Skor

\begin{tabular}{|c|c|c|c|c|}
\hline & \multirow[t]{2}{*}{ Menghitung skor tiap domain } & \multirow[t]{2}{*}{$\begin{array}{c}\text { Nilai } \\
\text { Mentah }\end{array}$} & \multicolumn{2}{|c|}{ Transfer Skor } \\
\hline & & & 4- 20 & $0-100$ \\
\hline Domain 1 & (6-Q3)+(6-4)+Q10+Q15+Q16+Q17+Q18 & $=$ & & \\
\hline Domain 2 & Q5+Q6+Q7+Q11+Q19+(6-Q26) & $=$ & & \\
\hline Domain 3 & $\mathrm{Q} 20+\mathrm{Q} 21+\mathrm{Q} 22$ & $=$ & & \\
\hline Domain 4 & Q8+Q9+Q12+Q13+Q14+Q23+Q24+Q25 & $=$ & & \\
\hline
\end{tabular}

Tabel II. Range Kualitas Hidup

\begin{tabular}{|c|c|}
\hline Total Skor Kuesioner & Tingkat Kualitas Hidup \\
\hline 100 & Sempurna \\
\hline $80-99$ & Tinggi \\
\hline $56-79$ & Sedang \\
\hline $1-55$ & Rendah \\
\hline 0 & Kematian \\
\hline
\end{tabular}

Tabel III. Penggunaan Obat Pada Pasien Hemodialisa di RS PKU Muhammadiyah Yogyakarta

\begin{tabular}{ccc}
\hline Nama Obat & Jumlah & Persentase \\
\hline Amlodipin & 76 & $75,25 \%$ \\
\hline Furosemid & 70 & $69,31 \%$ \\
\hline Candesartan & 58 & $57,43 \%$ \\
\hline Bisoprolol & 83 & $82,18 \%$ \\
\hline Hemapoetin & 56 & $55,45 \%$ \\
\hline Asam folat & 47 & $46,53 \%$ \\
\hline Antrain & 14 & $13,86 \%$ \\
\hline
\end{tabular}

\section{HASIL DAN PEMBAHASAN \\ Data Demografi Dasar}

Data demografi dasar berdasarkan jenis kelamin diperoleh dari data rekam medik. Hasil penelitian 101 responden, 45 diantaranya berjenis kelamin perempuan dan sisanya sebanyak 56 berjenis kelamin laki-laki. Hasil penelitian menunjukkan bahwa yang menjalani terapi hemodialisa lebih banyak diderita laki-laki daripada perempuan. Sesuai dengan Riskesdas (2013) bahwa berdasarkan jenis kelamin, prevalensi gagal ginjal kronis pada pria di Indonesia sebesar $0,3 \%$ dan pada wanita sebesar $0,2 \%$.

\section{Penggunaan Obat Pada Pasien Hemodialisa}

Berdasarkan data rekam medis pasien hemodialisa di RS PKU Muhammadiyah Yogyakarta obat yang diresepkan untuk pasien hemodialisa ada beberapa macam, yaitu antihipertensi, asam folat, hemapoetin, dan analgetik. Obat-obat yang diresepkan lebih dari dua obat. Antihipertensi diberikan kombinasi dua sampai empat obat karena pada pasien hemodialisa tekanan darah sulit dikontrol sehingga harus diberikan kombinasi dua sampai empat obat. Penggunaan obat yang diresepkan pada Tabel III.

Obat amlodipin, furosemid, candesartan, dan bisoprolol digunakan untuk mengontrol hipertensi dari pasien hemodialisa. Pada pasien hemodialisa biasanya digunakan kombinasi dua sampai empat obat antihipertensi. Hemapoetin digunakan untuk merangsang sumsum tulang untuk membuat sel-sel darah merah karena pada pasien hemodialisa hemoglobinnya dibawah normal sehingga pasien diberi hemapoetin jika tidak memungkinkan untuk menggunakan 
hemapoetin dan hemoglobin $<7 \mathrm{~g} / \mathrm{dL}$ maka dilakukan tranfusi darah. Asam folat berfungsi sebagai vitamin untuk pasien hemodialisa. Antrain berisi metamizol yang berfungsi sebagai analgetik dan antipiretik karena setelah pasien hemodialisis akan merasakan rasa sakit pada badannya.

Tabel IV. Kepatuhan Penggunaan Obat Pasien Hemodialisa RS PKU Muhammadiyah Yogyakarta

\begin{tabular}{ccc}
\hline Kepatuhan & Frekuensi & Persentase (\%) \\
\hline Patuh Tinggi & 59 & $58,42 \%$ \\
\hline Patuh Sedang & 9 & $8,91 \%$ \\
\hline Patuh Rendah & 33 & $32,67 \%$ \\
\hline Jumlah & 101 & $100 \%$ \\
\hline
\end{tabular}

Tabel V. Distribusi pasien per kriteria kepatuhan penggunaan obat pasien hemodialisa di RS PKU Muhammadiyah Yogyakarta

\begin{tabular}{|c|c|c|c|c|}
\hline Variabel Kepatuhan & Tidak & $\%$ & $\mathrm{Ya}$ & $\%$ \\
\hline Lupa minum obat & 80 & $79,21 \%$ & 21 & $20,79 \%$ \\
\hline Sengaja tidak minum obat dalam 3hari terakhir & 95 & $94,06 \%$ & 6 & $5,94 \%$ \\
\hline $\begin{array}{l}\text { Mengurangi atau tidak minum obat karena } \\
\text { kondisi memburuk }\end{array}$ & 87 & $86,14 \%$ & 14 & $13,86 \%$ \\
\hline Lupa membawa obat saat bepergian & 90 & $89,11 \%$ & 11 & $10,89 \%$ \\
\hline Kemarin meminum obat & 98 & $97,03 \%$ & 3 & $2,97 \%$ \\
\hline $\begin{array}{l}\text { Kadang-kadang tidak minum obat atau berhenti } \\
\text { minum obat karena kondisi membaik }\end{array}$ & 83 & $82,18 \%$ & 18 & $17,82 \%$ \\
\hline Kurang nyaman dalam meminum obat & 92 & $91,09 \%$ & 9 & $8,91 \%$ \\
\hline \multicolumn{5}{|l|}{ Tingkat kelupaan minum obat } \\
\hline - Tidak pernah lupa & & & 70 & $69,31 \%$ \\
\hline - Hampir tidak pernah lupa & & & 10 & $9,9 \%$ \\
\hline - Kadang-kadang lupa & & & 11 & $10,89 \%$ \\
\hline - Biasanya lupa & & & 10 & $9.9 \%$ \\
\hline - Selalu lupa & & & 0 & \\
\hline
\end{tabular}

Tabel VI. Skor rata-rata tiap domain dan skor yang memiliki dibawah rata-rata

\begin{tabular}{|c|c|c|c|c|}
\hline Domain & $\begin{array}{l}\text { Nilairata-rata } \\
\text { Mean } \pm \text { SD }\end{array}$ & & itas hidup & $\begin{array}{c}\text { Jumlah } \\
\text { Responden }\end{array}$ \\
\hline \multirow{3}{*}{ Domain 1 (Fisik) } & \multirow{3}{*}{$53.47 \pm 9.05$} & $<53.47$ & Rendah & 39 \\
\hline & & $=53.47$ & Sedang & 0 \\
\hline & & $>53.47$ & Tinggi & 62 \\
\hline \multirow{3}{*}{$\begin{array}{c}\text { Domain } 2 \\
\text { (Mental) }\end{array}$} & \multirow{3}{*}{$57.85 \pm 14.33$} & $<57.85$ & Rendah & 47 \\
\hline & & $=57.85$ & Sedang & 0 \\
\hline & & $>57.85$ & Tinggi & 54 \\
\hline \multirow{3}{*}{$\begin{array}{l}\text { Domain } 3 \\
\text { (Sosial) }\end{array}$} & \multirow{3}{*}{$66.24 \pm 16.19$} & $<66.24$ & Rendah & 34 \\
\hline & & $=66.24$ & Sedang & 0 \\
\hline & & $>66.24$ & Tinggi & 67 \\
\hline \multirow{3}{*}{$\begin{array}{c}\text { Domain } 4 \\
\text { (Lingkungan) }\end{array}$} & \multirow{3}{*}{$65.14 \pm 13.11$} & $<65.14$ & Rendah & 33 \\
\hline & & $=65.14$ & Sedang & 0 \\
\hline & & $>65.14$ & Tinggi & 68 \\
\hline
\end{tabular}


Tabel VII. Distribusi Jumlah Pasien Berdasarkan Tingkat Kepatuhan dan Kualitas Hidup untuk Tiap Domain

\begin{tabular}{ccccc}
\hline \multirow{2}{*}{ Kepatuhan } & \multicolumn{5}{c}{ Domain } \\
\cline { 2 - 5 } & Domain 1 & Domain 2 & Domain 3 & Domain 4 \\
\hline Tinggi & 64 & 55 & 63 & 55 \\
\hline Sedang & 8 & 7 & 9 & 9 \\
\hline Rendah & 29 & 39 & 101 & 37 \\
\hline Jumlah & 101 & 101 & 101 \\
\hline
\end{tabular}

Tabel VIII. Hubungan antara Kepatuhan Penggunaan Obat dengan Kualitas Hidup Pasien Hemodialisa di RS PKU Muhammadiyah Yogyakarta

\begin{tabular}{|c|c|c|c|c|}
\hline \multirow{2}{*}{\multicolumn{2}{|c|}{ Kepatuhan }} & \multicolumn{2}{|c|}{ Kualitas Hidup } & \multirow{2}{*}{$\mathrm{P}$} \\
\hline & & Rendah & Tinggi & \\
\hline \multirow{3}{*}{ Domain 1} & Tinggi & 10 & 54 & \multirow{3}{*}{0,000} \\
\hline & Sedang & 4 & 4 & \\
\hline & Rendah & 23 & 6 & \\
\hline \multirow{3}{*}{ Domain 2} & Tinggi & 15 & 40 & \multirow{3}{*}{0,000} \\
\hline & Sedang & 3 & 4 & \\
\hline & Rendah & 22 & 17 & \\
\hline \multirow{3}{*}{ Domain 3} & Tinggi & 5 & 58 & \multirow{3}{*}{0,000} \\
\hline & Sedang & 5 & 4 & \\
\hline & Rendah & 23 & 5 & \\
\hline \multirow{3}{*}{ Domain 4} & Tinggi & 1 & 54 & \multirow{3}{*}{0,000} \\
\hline & Sedang & 5 & 4 & \\
\hline & Rendah & 28 & 9 & \\
\hline
\end{tabular}

\section{Kepatuhan Terapi}

Tabel IV menunjukkan presentase tingkat kepatuhan penggunaan obat pada pasien hemodialisa di RS PKU Muhammadiyah Periode Maret 2015 bahwa dari 101 pasien.

Kepatuhan pasien merupakan hal yang penting untuk meningkatkan keberhasilan terapi. Pada penelitian ini pasien dengan kepatuhan tinggi sebesar $58,42 \%$, hal ini menunjukkan bahwa pasien hemodialisa di RS PKU Muhammadiyah Yogyakarta sudah menggunakan obat sesuai dengan aturan yang di tuliskan dalam resep. Harapan jika pasien menggunakan obat sesuai dengan aturan pakai adalah ketercapian tujuan terapi, sehingga dapat meningkatkan kualitas hidup pasien.

Tabel V merupakan tabel distribusi per kriteria kepatuhan penggunaan obat yang terdapat dalam kuisioner MMAS, Tingkat kepatuhan pasien berdasarkan hasil kesioner yang menunjukkan perilaku pasien terhadap bagaimana menggunakan obat. Kuesioner ini sangat penting untuk di ketahui sebagai sumber informasi dan evaluasi untuk tenaga kesehatan dalam meberikan informasi dan konseling kepada pasien untuk meningkatkan kepatuhan pasien. Berdasarkan hasil penelitian diperoleh data kepatuhan pasien seperti pada Tabel V.

Berdasarkan Tabel $\mathrm{V}$ responden menjawab "ya" tidak mengkonsumsi obat karena lupa, sibuk, atau malas dalam minum obat dengan alasan tidak nyaman dan obat yang diberikan lebih sedikit daibandingkan responden yang menjawab tidak.

Pasien berhenti atau tidak minum obat karena merasa kondisinya membaik. Sebanyak 18 dari 101 responden. Responden mengaku jika kondisinya membaik lebih memilih berhenti tidak minum obat karena merasa malas dan kondisinya baik-baik saja tanpa obat tersebut. Adapun yang memberikan alasan karena memilih berhenti minum obat karena walaupun obat diminum terus menerus 
tetapi ginjalnya tidak akan membaik dan penyakitnya tidak akan sembuh.

Beberapa responden enggan meminum obat karena merasa tidak terdapat perbedaan setelah minum obat dan malah merasa kondisinya memburuk. Kondisi penderita gagal ginjal tidak hanya terletak pada kepatuhan penggunaan obat tetapi juga kepatuhan diet seperti yang sudah disampaikan oleh dokter atau petugas medis lainnya.

Kelemahan dari kuisioner ini adalah tidak dapat dilakukan untuk masyarakat yang buta huruf dan apabila responden tidak dapat memahami pertanyaan maka akan terjadi kemacetan dan kesalahan persepsi sehingga pertanyaan tidak dijawab seluruhnya atau salah menjawab pertanyaan karena bahasanya yang rumit sehingga sulit dipahami. Kelemahan lainnya kuisioner ini adalah tidak mengukur secara keseluruhan kepatuhan penggunaan obat misal waktu dan frekuensi penggunaan obat.

\section{Kualitas Hidup Responden}

Kualitas hidup responden dapat diketahui dari total nilai kuisioner WHOQOL. Kuisioner WHOQOL berisi 24 pertanyaan dengan 4 domain, yaitu domain fisik terdiri dari 7 item, mental terdiri dari 6 item, sosial terdiri dari 3 item, dan lingkungan terdiri dari 8 item. Total dari keseluruhan 24 pertanyaan dan ditambah 2 pertanyaan yang menggambarkan kesehatan umum.

Setelah di rata-rata skor tiap domain kemudian dihitung responden yang memiliki skor dibawah rata-rata, sama dengan rata-rata dan diatas rata-rata. Semakin banyak yang memiliki skor dibawah rata-rata pada setiap domain berarti pada domain tersebut sulit untuk dicapai kualitas hidup yang baik.

Pada Tabel VI terlihat bahwa domain fisik sebanyak 39 responden memiliki skor dibawah rata-rata. Pada domain mental sebanyak 47 responden yang memiliki skor dibawah rata-rata. Pada domain sosial 34 responden memiliki skor dibawah rata-rata. Dan pada domain lingkungan sebanyak 33 responden memiliki skor dibawah rata-rata. Dari ke empat domain tersebut menyebutkan bahwa domain mental memiliki responden terbanyak yang skor dibawah ratarata itu menunjukkan bahwa pada penderita gagal ginjal selain fisik, kondisi mental atau psikologis sangat berpengaruh pada kualitas hidup pasien.

Pada domain lingkungan terdapat 33 responden yang memiliki nilai skor rata-rata, paling rendah jumlah respondennya daripada domain yang lain. Domain lingkungan merupakan bagaimana kehidupan di lingkungannya terhadap responden. Keadaan dan kondisi dari lingkungan sekitar juga dapat berpengaruh pada kesehatan mental atau psikologisnya.

\section{Hubungan Antara Tingkat Kepatuhan dengan Kualitas Hidup}

Kepatuhan dapat mempengaruhi tingkat kualitas hidup terutama untuk penyakit yang memiliki pengobatan jangka panjang. Pada Tabel VII dapat dilihat hubungan tingkat kepatuhan dengan kualitas hidup.

Pada penelitian ini analisis multivarian menggunakan regresi linear. Berdasarkan hasil penelitian dan analisis data dapat diketahui hubungan penggunaan obat dengan kualitas hidup pasien hemodialisa di RS PKU Muhammadiyah Yogyakarta seperti dalam Tabel VIII.

Pada Tabel VIII ditunjukkan hubungan antara kepatuhan penggunaan obat dengan kualitas hidup pada setiap domainnya. responden memiliki tingkat kepatuhan serta kualitas hidup. Responden yang memiliki kepatuhan tinggi dan memiliki kualitas hidup yang tinggi sadar dengan kesehatannya dan memiliki pengetahuan yang luas terhadap gagal ginjal serta dukungan dari orang-orang disekitarnya.

Responden yang tidak patuh dan kualitas hidupnya rendah kemungkinan karena obat tidak memebrikan efek terapi maksimal. Menurunnya kondisi fisik juga merupakan salah satu faktor dari kualitas hidup pasien 
yang rendah. Menurunnya kondisi fisik juga dapat disebabkan oleh faktor umur dan riwayat penyakit, karena semakin tinggi umur maka kondisi fisik juga semakin menurun dan energi yang dihasilkan pun tidak banyak.

Berdasarkan data uji statistik dengan menggunakan regresi linear didapat nilai $\mathrm{p}=0,000$ $(\mathrm{p}<0,05)$ maka dapat disimpulkan bahwa ada hubungan antara kepatuhan penggunaan obat dengan kualitas hidup pasien hemodialisa di RS PKU Muhammadiyah Yogyakarta Periode Maret 2015.

Hasil penelitian ini sama dengan penelitian yang sebelumnya yang dilakukan oleh GarciaLlana, dkk., 2013 menyatakan bahwa kepatuhan pada pengobatan pengikat fosfat pada pasien hemodialisis sebesar 72,9\%. Faktor yang dapat mempengaruhi kepatuhan penggunaan obat pada pasien hemodialisa adalah faktor depresi, kecemasan, dan stres. Hubungan antara kepatuhan, untuk obat anti hipertensi dan pengikat fosfat dan faktor psikologis dan kualitas hidup menyatakan bahwa pasien yang meminum obat secara rutin dan tepat waktu memiliki fisik yang lebih baik dan atau kuat sehingga dapat mempengaruhi kualitas hidup. Penelitian ini juga menyimpulkan bahwa pasien memiliki tingkat kepatuhan yang rendah terhadap pengobatan oral apabila memiliki tingkat emosional yang tinggi sehingga dapat berpengaruh pada kualitas hidup pasien. Mengetahui secara dini faktor-faktor dalam kualitas hidup dapat meningkatkan kesehatan fisik dan mental pasien gagal ginjal kronis.

\section{Analisis Regresi Linear}

Analisis regresi linear digunakan untuk mengetahui pengaruh dari variabel kepatuhan penggunaan obat terhadap kualitas hidup pasien hemodialisa yang kemudian dilakukan pada tiap domain

Pada domain 1 menunjukkan $\mathrm{R}$ Square sebesar 0,361 yang artinya adalah bahwa variabel domain 1 (fisik) berpengaruh terhadap kepatuhan penggunaan obat sebesar $36,1 \%$ dan $63,9 \%$ sisanya dipengaruhi oleh faktor lain. Hal tersebut untuk nilai dari Adjusted R Square sebesar 0,354 yang artinya sama dengan $\mathrm{R}$ square. Pada uji ANOVA memiliki tingkat signifikansinya sebesar 0,000 yang artinya variabel domain 1 berpengaruh secara signifikan terhadap variabel kepatuhan.

Pada domain 2 menunjukkan $\mathrm{R}$ Square sebesar 0,385 yang artinya adalah bahwa variabel domain 2 (mental) berpengaruh terhadap kepatuhan penggunaan obat sebesar $38,5 \%$ dan $61,5 \%$ sisanya dipengaruhi oleh faktor lain. Hal tersebut untuk nilai dari Adjusted R Square sebesar 0,378 yang artinya sama dengan $R$ square. Pada uji ANOVA memiliki tingkat signifikansinya sebesar 0,000 yang artinya variabel domain 2 berpengaruh secara signifikan terhadap variabel kepatuhan

Pada domain 3 menunjukkan $\mathrm{R}$ Square sebesar 0,496 yang artinya adalah bahwa variabel domain 3 (sosial) berpengaruh terhadap kepatuhan penggunaan obat sebesar $49,6 \%$ dan $50,4 \%$ sisanya dipengaruhi oleh faktor lain. Hal tersebut untuk nilai dari Adjusted $\mathrm{R}$ Square sebesar 0,491 yang artinya sama dengan $R$ square. Pada uji ANOVA memiliki tingkat signifikansinya sebesar 0,000 yang artinya variabel domain 3 berpengaruh secara signifikan terhadap variabel kepatuhan

Pada domain 4 menunjukkan $\mathrm{R}$ Square sebesar 0,580 yang artinya adalah bahwa variabel domain 4 (lingkungan) berpengaruh terhadap kepatuhan penggunaan obat sebesar $58 \%$ dan $42 \%$ sisanya dipengaruhi oleh faktor lain. Hal tersebut untuk nilai dari Adjusted R Square sebesar 0,576 yang artinya sama dengan $\mathrm{R}$ square. Pada uji ANOVA memiliki tingkat signifikansinya sebesar 0,000 yang artinya variabel domain 4 berpengaruh secara signifikan terhadap variabel kepatuhan

\section{KESIMPULAN}

Kepatuhan penggunaan obat pasien hemodialisa di RS PKU Muhammadiyah Yogyakarta periode Maret 2015 memiliki kepatuhan penggunaan obat kriteria tinggi sebanyak 59 orang $(58,42 \%)$, kepatuhan penggunaan obat kriteria sedang sebanyak 9 
orang $(8,91 \%)$ dan yang memiliki kriteria rendah sebanyak 33 orang $(32,67 \%)$

Kualitas hidup pasien hemodialisa di RS PKU Muhammadiyah Yogyakarta periode Maret 2015 memiliki kualitas hidup kriteria kualitas hidup sedang 70 orang $(69,31 \%)$ dan yang memiliki kualitas hidup rendah sebanyak 31 orang $(30,69 \%)$

Hasil penelitian ini menunjukkan bahwa kepatuhan penggunaan obat berpengaruh signifikan terhadap kualitas hidup pasien hemodialisa $(\mathrm{P}<0,05)$ pada semua domain dengan menggunakan kuisioner WHOQOL-Bref.

\section{UCAPAN TERIMA KASIH}

Penulis mengucapkan terima kasih kepada pihak RS PKU Muhammadiyah Yogyakarta dan semua pihak lain yang sudah berpartisipasi dalam studi ini.

\section{DAFTAR PUSTAKA}

Anonim, 2014. Center for Disease Control and Prevention-National Center for Health Statixtics: Morbidity Adults with Diagnose Kidney Disease, http:// www.cdc.gov.nchs.htm

Baradero, M, Dayrit, M.W., Siswandi, Y., 2008. Seri Asuhan Keperawatan Pada Klien Gangguan Ginjal. Jakarta, EGC, 148.

Brunner, F.P., \& Suddarth, N.H., 2001. End-Stage Renal failure due to analgesic nephropathy, its changing pattern and cardiovascular mortality. Nephrol Dial Transplant, 9, 1371-1376.

Carol, W, 2013. Common Medication for People receiving Haemodialysis. Birmingham. Renal Unit Queen Elizabeth Hospital Birmingham.
Departemen Kesehatan RI, 2013. Laporan Riskesdas 2013. http://www.depkes.go.id/resources/downlo ad/general/Hasil\%20Riskesdas\%202013.pd f., diakses pada tanggal 30 April 2015.

Garcia-Llana, Remor, E., Selgas, R. 2013. Adherence to treatment, emotional state and quality of life in patients with endstage renal disease undergoing dialysis. Psicothema, 25(1), 79-86.

Hussar, D.A., 1995. Drug Interaction, Remington : The Science and Practise of Pharmacy, vol 11, 19th Ed. Pennsylvania, Mack Publishing Companya Easton, 18221836.

Ibrahim S., Hossam M., Belal D., 2015. Study of Non-Compliance among Chronic Hemodialysis Patient Its Impact on Patient's Outcomes, Saudi J Kidney Dis Transpl., 26(2), 243-249.

Indonesian Renal Registry, 2012. Data Penderita Gagal Ginjal Kronik yang Menjalani Hemodialisis. Jawa Barat.

National Kidney Foudation, 2015. Kidney Disease Outcome Quality Initiative, Cinical Practice Guidline for Hemodialysis Adequacy. http://www. Kidney.org/professional/KDOQI/ Guidline_ckd/p4.htm

Zyoud, S.H., Daraghmeh, D.N., Mezyed D.O. et al , 2016, Factors affecting quality of life in patients on haemodialysis: a cross-sectional study from Palestine, BMC Nephrology, 17,44 . 